\title{
PENERAPAN INTELLIGENT GEOGRAPHIC INFORMATION SYSTEM UNTUK DETEKSI KECANDUAN GAME
}

\author{
Anastasya Latubessy*1, Ahmad Jazuli², Rina Fiati ${ }^{3}$ \\ ${ }^{123}$ Universitas Muria Kudus \\ Email: ${ }^{1}$ anastasya.latubessy@umk.ac.id, ${ }^{2}$ ahmad.jazuli@umk.ac.id, ${ }^{3}$ rina.fiati@umk.ac.id \\ *Penulis Korespondensi
}

(Naskah masuk: 05 Juli 2019, diterima untuk diterbitkan: 26 November 2020)

\begin{abstract}
Abstrak
Segala sesuatu yang berlebihan dapat menimbulkan efek kecanduan. Hal yang sama juga berlaku untuk game. Game dapat memberikan efek adiksi yang mengakibatkan pemainnya ketagihan. Pemain game tidak mengenal batas usia. Anak-anak bahkan anak usia dini sudah bermain game dengan menggunakan gadget, sebagai akibat dari perkembangan teknologi saat ini. Kecanduan game dapat berdampak negatif pada anak usia dini. Penelitian terdahulu menunjukkan adanya hubungan korelasi negatif antara kecanduan game dengan proses pembelajaran. Meninjau hal tersebut, maka orang tua perlu waspada terhadap pola permainan game anak. Penelitian terdahulu menghasilkan aplikasi untuk mendeteksi tingkat kecanduan game anak dengan menggunakan salah satu metode dalam sistem pakar yaitu backward chaining untuk identifikasi gejala kecanduan game. Penelitian saat ini mengkombinasi teknologi pakar pada aplikasi sebelumnya dengan teknologi Geographic Information System untuk mendeteksi kecanduan game anak dan memetakan persebarannya di wilayah Indonesia bagian timur, barat dan tengah. Penelitian ini menggunakan metode perancangan sistem waterfall, yang dimulai dari identifikasi masalah, analisa masalah, perancangan sistem, implementasi dan pengujian sistem. Sehingga menghasilkan aplikasi yang diberi nama IGIS-Decandu(Intelligent Geographic Information System Deteksi Kecanduan Game) yang dapat digunakan untuk mengetahui tingkat persebaran kecanduan game anak Indonesia. Hasil uji coba untuk pengujian identifikasi kecanduan game antara sistem IGIS-Decandu dan ujicoba manual memperoleh nilai Kappa sebesar 1.0. Berdasarkan pengujian tersebut, dapat disimpulkan bahwa sistem IGIS-Decandu siap untuk digunakan secara umum, karena proses identifikasi kecanduan game valid dengan nilai keeratan kesepakatan antara pengujian sistem dan manual adalah 1.00 yang berarti "Sangat Kuat".
\end{abstract}

Kata kunci: intelligent, GIS, deteksi, kecanduan, game, pemetaan

\section{APPLICATION OF THE INTELLIGENT GEOGRAPHIC INFORMATION SYSTEM FOR DETECTION OF GAME ADDICTIONS}

\begin{abstract}
Anything that is excessive can have an addictive effect. The same thing applies to games. Games can have an addictive effect that results in players being addicted. Gamers don't know the age limit. Children and even young children are already playing games using gadgets, as a result of current technological developments. Game addiction can have a negative impact on early childhood. Previous research has shown a negative correlation between game addiction and the learning process. Reviewing this, parents need to be aware of the pattern of children's game play. Previous research has made an application to detect the level of addiction to children's by using one method in the expert system that is backward chaining to identify the symptoms of game addiction. Current research combines expert technology in previous applications with Geographic Information System technology to detect children's gaming addictions and map their distribution in eastern, western and central Indonesia. This study uses a waterfall system design method, which start from identification, problem analysis, design system, implementation system and testing system to produce an application called IGIS-Decandu (Intelligent Geographic Information System for Game Addiction Detection) that can be used to determine the level of distribution of Indonesian children's game addiction. The results of trials for testing the game addiction identification between the IGIS-Decandu system and manual testing obtained a Kappa value of 1.0. Based on these tests, it can be concluded that the IGIS-Decandu system is ready for general use, because the process of identifying game addiction is valid with the value of the agreement between the system and manual testing being 1.00 which means "Very Strong"
\end{abstract}

Keywords: intelligent, GIS, detection, addiction, game, mapping 


\section{PENDAHULUAN}

Mengingat WHO telah menetapkan kecanduan game sebagai salah satu gangguan kejiwaan yang tertuang dalam International Statistical Classification of Diseases and Related Health Problems (ICD)-11 tahun 2019. Banyak kasus anak usia dini teridindikasi kecanduan game. Untuk mengantasipasinya dirasa perlu untuk mendata tingkat kecanduan game anak-anak di Indonesia. Bagaimana cara mendata tingkat kecanduan game tersebut? IGIS-Decandu dikembangkan untuk menjawab pertanyaan tersebut. IGIS-Decandu menggabungkan teknologi pakar dan teknologi GIS untuk melakukan identifikasi kecanduan game seseorang, kemudian hasilnya dipetakan pada map sesuai dengan asal kota dari anak yang diidentifikasi. Alasan yang mendasari pembuatan aplikasi ini dilatarbelakangi oleh beberapa studi penelitian yang telah dilakukan sebelumnya.

Kecanduan game tidak mengenal usia. Kecanduan game dapat mempengaruhi perilaku remaja dan berdampak negatif (Ulfa,M., 2017). Terlalu sering bermain game dapat menimbulkan ketergantungan (Syahran, R., 2015). Dampak negatif yang ditimbulkan berpengaruh pada menurunnya prestasi belajar (Ariantoro,T.R, 2016).

Disamping itu, kecanduan game online juga akan mempengaruhi keterampilan sosial (Setiaji,S. dan Virlia, S., 2016). Terdapat hubungan anatar interaksi sosial dan konsep diri dengan kecanduan game (Ayu,L dan Saragih S., 2016). Namun, disisi lain ada yang berpendapat lain, bahwa tidak ada hubungan antara kecerdasan emosi dan kecanduan game (Misnawati, 2016). Memang banyak pro dan kontra tentang kecanduan game ini, walaupun WHO sendiri telah menyatakan kecanduan game sebagai salah satu gangguan kejiwaan.

Telah dilakukan penelitian sebelumnya untuk melihat adakah hubungan antara adiksi game dengan proses belajar anak. Hasil penelitian menyimpulkan bahwa terdapat hubungan korelasi negatif antara keduanya, yang berarti semakin tinggi adiksi pada game maka proses belajar akan menurun (Latubessy,A dan Ahsin,M.N., 2016). Penelitian lainnya juga telah melakukan pemodelan untuk proses identifikasi kecanduan game menggunakan salah satu model dalam sistem pakar yaitu backward chaining (Latubessy,A dan Wijayanti, E., 2017). Model tersebut juga telah diuji coba dengan melakukan analisis pada model penelusurannya (Latubessy,A dan Jazuli, A.,2017). Berdasarkan pemodelan dan uji coba model maka pada tahun berikutnya telah dibuat sebuah aplikasi berbasis web untuk identifikasi kecanduan game. Aplikasi tersebut menggunakan salah satu metode dalam sistem pakar yaitu backward chaining untuk identifikasi gejala kecanduan game (Latubessy, A dan Jazuli, A., 2018).

Penelitian saat ini, mengembangkan aplikasi lama yang dibuat penulis sebelumnya dengan menambahkan teknologi GIS untuk memetakan peta kecanduan game. Aplikasi ini diberi nama IGISDecandu(Intelligent Geographic Information SystemDeteksi Kecanduan Game).

Teknologi GIS dapat digunakan dalam berbagai bidang dalam memetakan daerah atau wilayah tertentu. Seperti pada penelitian berikut yang melakukan pemetaan wilayah yang teridentifikasi banjir menggunakan GIS (Fiati, R dan Latubessy, A., 2016).

\section{METODE PENELITIAN}

Metode penelitian yang digunakan dalam pengembangan sistem adalah model waterfall, dimana diawali dengan identifikasi, analisa masalah, analisa kebutuhan, perancangan, impelentasi sistem dan pengujian sistem secara berurutan. Urutan penelitian ditunjukkan pada Gambar 1. Model waterfall dipilih karena proses pembuatan sistem ini membutuhkan tahapan-tahapan yang dikerjakan dengan detail. Dimana, satu tahap harus dikerjakan dengan tuntas untuk beralih ke tahapan berikutnya. Hal tersebut dilakukan untuk meminimalisasi kesalahan dalam pengerjaan sistem.

Pada tahap Identifikasi dilakukan identifikasi terhadap masalah yang ada serta referensi dari berbagai sumber baik pakar psikolog pengembangan anak maupun referensi ilmiah dari beberapa bahan pustaka. Dilanjutkan dengan melakukan analisa masalah serta analisa kebutuhan sistem. Analisa kebutuhan sistem dibagi atas kebutuhan fungsional sistem dan kebutuhan non fungsional sistem. Tahap ini penulis menentukan berapa pengguna sistem dan apa yang bisa dilakukan setiap pengguna terhadap sistem. Terdapat empat pengguna yaitu, admin, pakar, orangtua/wali anak, dan guest.

Tahap berikutnya adalah perancangan. Perancangan sistem dilakukan menggunakan pendekatan object oriented dengan menggunakan beberapa diagram UML (Unified Modelling Language). Pada tahap perancangan dilakukan kolaborasi sistem dengan menambahkan metode GIS pada sistem Decandu. Metode GIS ditambahkan agar sistem dapat menampilkan peta wilayah berdasarkan hasil identifikasi kecanduan game.

Setelah perancangan selesai, maka dilakukan implementasi sistem menggunakan bahasa pemrograman PHP dan database MySQL. Tahapan terakhir adalah pengujian sistem. Pengujian dilakukan dengan menggunakan blackbox testing untuk menguji fungsionalitas sistem apakah sudah berjalan dengan baik sesuai fungsinya. Pengujian juga dilakukan uji validasi sistem dengan menggunakan Koefisien Kapha. 


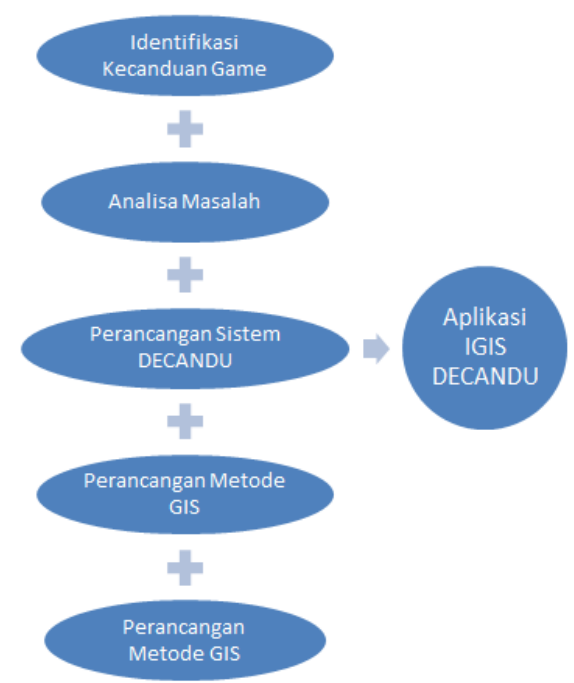

Gambar 1. Metodologi Penelitian IGIS-Decandu

\section{HASIL DAN PEMBAHASAN}

\subsection{Implementasi Sistem}

Pengembangan IGIS-Decandu menambahkan fitur untuk pemetaan dengan teknologi GIS. Fitur ini ditambahkan untuk melihat persebaran tingkat kecanduan game dibeberapa wilayah Indonesia. Platform game yang dimaksud adalah Game Online, yaitu jenis game yang menggunakan jaringan komputer seperti internet.

Identifikasi wilayah dilakukan berdasarkan kota atau tempat tinggal Orang tua atau wali yang diisi saat proses regstrasi, seperti yang ditunjukkan pada Gambar 2. Identifikasi dilakukan berdasarkan asal kota dari orang tua atau wali anak. Dengan asumsi bahwa, anak-anak akan tinggal satu kota dengan orang tua atau wali mereka.

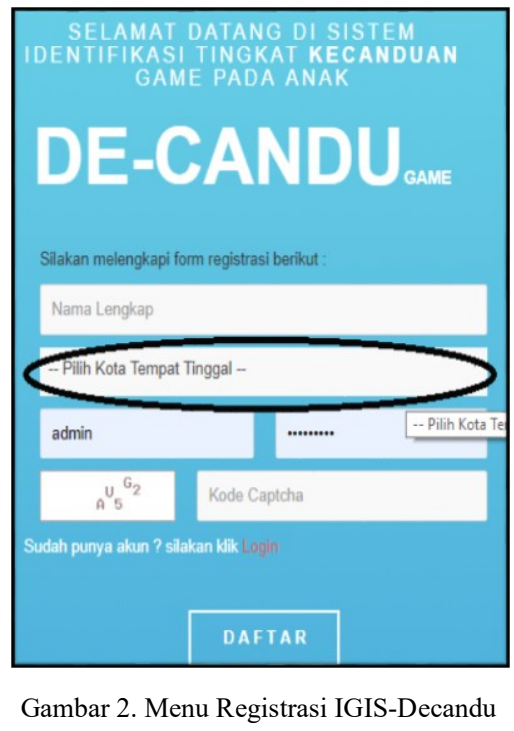

Gambar 3 menunjukkan tiga menu yang ada pada aplikasi sebelumnya. Menu Konsultasi, Laporan
Konsultasi dan Ubah Data Profil masih dibuat dalam aplikasi yang baru saat ini.

Pada menu konsultasi, disajikan dua belas pernyataan yang merupakan gejala kecanduan game. Pernyataan tersebut berhubungan dengan enam jenis perilaku kecanduan game yaitu Salience, Euphoria, Conflict, Tolerance, Withdrawal, Relapse dan Reinstatement. Seseorang dikatakan kecanduan game jika teridindikasi minimal tiga dari enam jenis kecanduan game tersebut. Sistem IGIS-Decandu menggunakan salah satu metode dalam sistem pakar yaitu backward chaining untuk penelusuran kedua belas gejala tersebut berdasarkan jawaban responden.

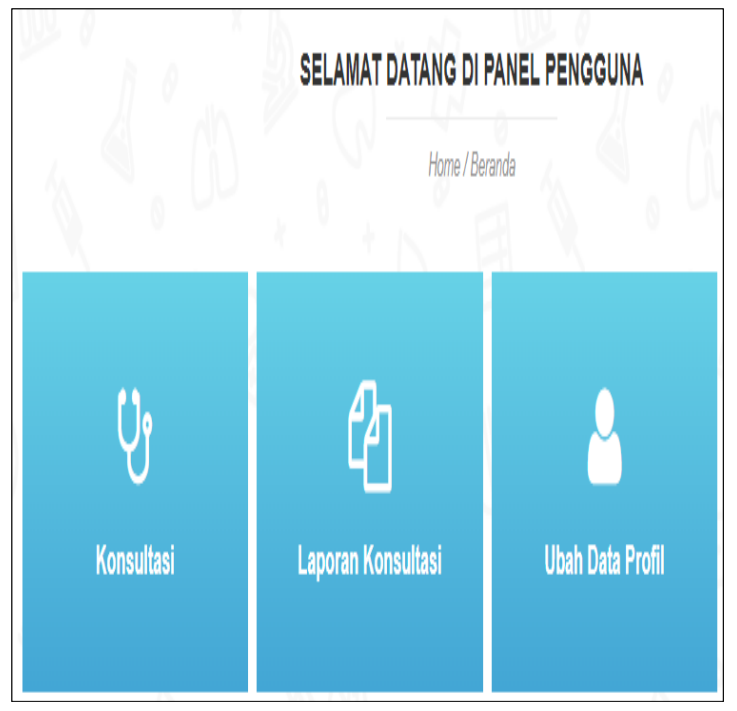

Gambar 3. Menu Pengguna yang Lama

Adapun menu tambahan pada aplikasi IGISDecandu adalah peta kecanduan dan grafik pemetaan. Tombol menu peta kecanduan dan tombol menu grafik pemetaan ditunjukkan pada Gambar 4.

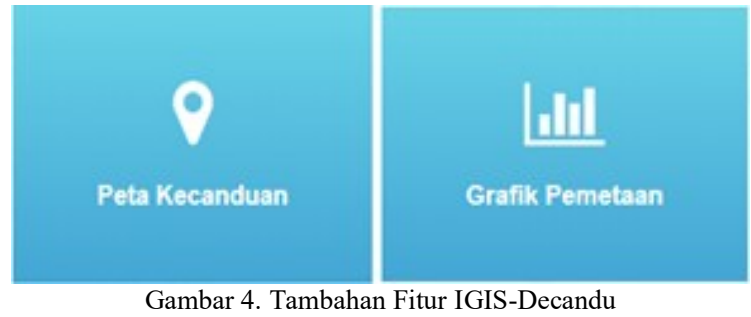

Menu peta kecanduan menampilkan peta wilayah Indonesia dengan titik-titik lokasi daerah yang telah dilakukan identifikasi. Sementara menu grafik pemetaan menampilkan grafik berdasarkan kategori wilayah, kelompok usia, jenis kelamin dan hasil identifikasinya.

Peta wilayah Indonesia ditampilkan untuk melihat persebaran tingkat kecanduan game anakanak Indonesia, seperti yang ditunjukkan pada Gambar 5. Data yang ditampilkan pada peta merupakan hasil identifikasi berdasarkan konsultasi pada menu konsultasi di sistem IGIS-Decandu. 


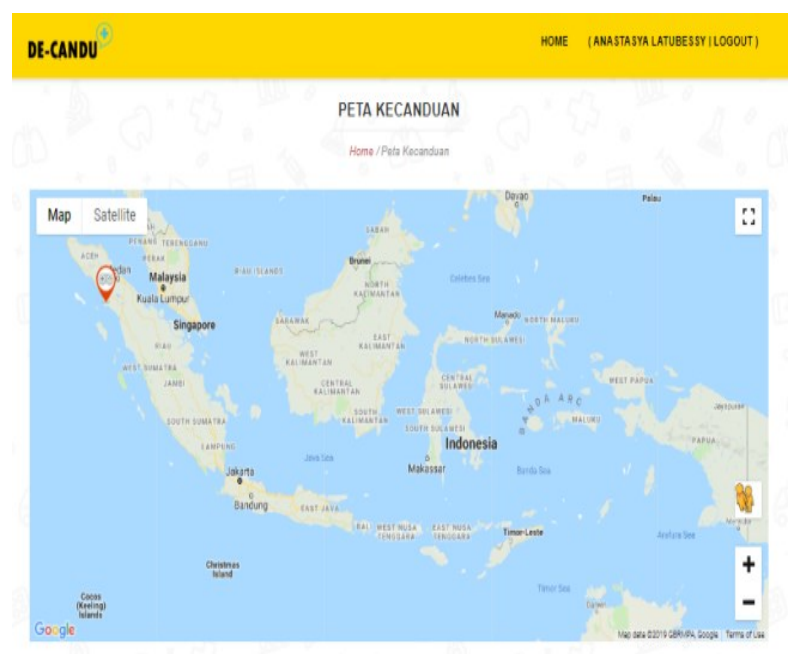

Gambar 5. Peta Identifikasi Kecanduan

Penjelasan icon pada peta ditunjukkan pada Gambar 6. Dimana akan terdapat data hasil identifikasi pada kota tersebut, dengan informasi jumlah responden, jumlah kecanduan dan jumlah yang tidak kecanduan.

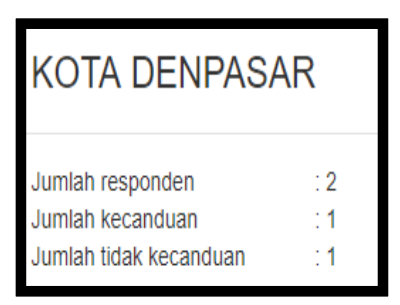

Gambar 6. Penjelasan icon pada peta

Menu grafik akan menampilkan data jumlah responden yang kecanduan maupun tidak kecanduan kedalam bentuk grafik. Grafik ditampilkan berdasarkan beberapa kategori yaitu, wilayah, usia, jenis kelamin dan total identifikasi. Grafik wilayah ditunjukkan pada Gambar 7. Tampilan grafik merupakan data uji coba sementara.

\section{Grafik Jumlah Wilayah}

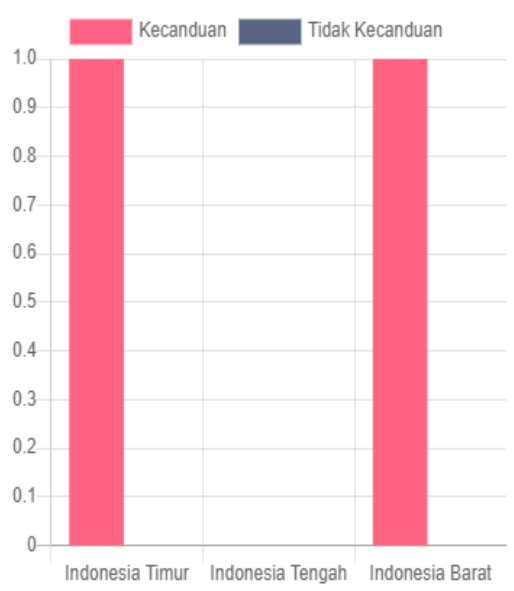

Gambar 7. Tampilan Grafik Wilayah
Kelompok usia dikategorikan dalam dua kelompok. Kelompok usia enam sampai delapan tahun dan kelompok usia sepuluh sampai sebelas tahun. Grafik kelompok usia ditunjukkan pada Gambar 8.

\section{Grafik Jumlah Kelompok Usia}

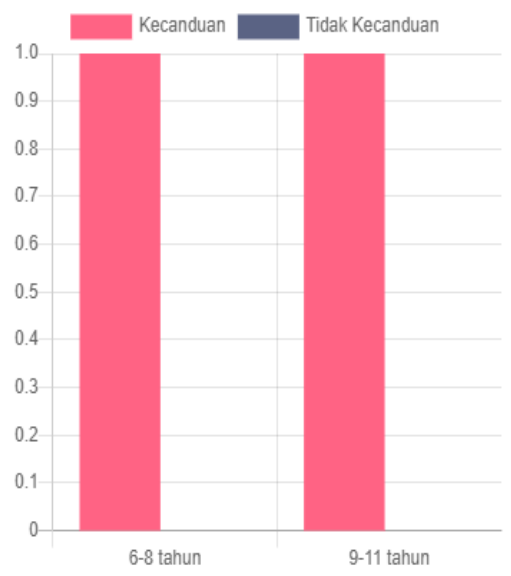

Gambar 8. Tampilan Grafik Kelompok Usia

Gambar 9 menunjukkan tampilan untuk grafik yang diidentifikasi sesuai jenis kelamin. Grafik ini disajikan dalam bentuk pie sementara grafik lainnya dalam bentuk grafik batang.

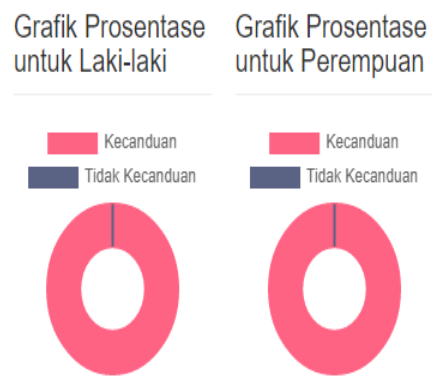

Gambar 9. Tampilan Gafik Berdasarkan Jenis Kelamin

\subsection{Pengujian Sistem}

Pengujian sistem dilakukan dengan menggunakan metode pengujian Blackbox Testing. Dimana, menu yang diuji adalah menu tambahan yang adalah pengembangan sistem dari sistem sebelumnya yaitu, menu Identifikasi Berdasarkan Kota asal Orang tua, menu Grafik dan Peta. Hasil pengujian ditunjukkan pada Tabel 1 .

Uji coba dilakukan menggunakan empat belas skenario pengujian dan dibagi dalam dua tahapan pengujian. Hasil percobaan tahap pertama masih mengalami kegagalan pada skenario pengujian kesepuluh. Sistem belum dapat menampilkan data kelompok usia sembilan sampai sebelas pada grafik yang tepat. Oleh sebab itu, dilakukan perbaikan sistem sehingga pada uji coba tahap kedua, sistem berhasil melewati setiap skenario pengujian. 
Tabel 1. Pengujian Blackbox IGIS-Decandu

\begin{tabular}{|c|c|c|c|}
\hline No & Skenario Pengujian & $\begin{array}{c}\text { Hasil Uji } \\
\text { Coba Tahap } \\
1 \\
\end{array}$ & $\begin{array}{c}\text { Hasil Uji } \\
\text { Coba Tahap } \\
2 \\
\end{array}$ \\
\hline 1. & $\begin{array}{lr}\text { Penambahan } & \text { user } \\
\text { dengan asal } & \text { kota } \\
\text { diwilayah } & \text { Indonesia } \\
\text { Timur } & \end{array}$ & Berhasil & Berhasil \\
\hline 2 & $\begin{array}{l}\text { Penambahan } \\
\text { dengan aser } \\
\text { diwilayah Indonesia } \\
\text { Tengah }\end{array}$ & Berhasil & Berhasil \\
\hline 3. & $\begin{array}{l}\text { Penambahan user } \\
\text { dengan asal kota } \\
\text { diwilayah Indonesia } \\
\text { Barat }\end{array}$ & Berhasil & Berhasil \\
\hline 4. & $\begin{array}{l}\text { Menampilkan Peta } \\
\text { Indonesia }\end{array}$ & Berhasil & Berhasil \\
\hline 5. & $\begin{array}{l}\text { Melakukan } \\
\text { identifikasi untuk } \\
\text { setiap user dibeberapa } \\
\text { wilayah Indonesia }\end{array}$ & Berhasil & Berhasil \\
\hline 6. & $\begin{array}{l}\text { Menampilkan Grafik } \\
\text { Hasil Identifikasi } \\
\text { Berdasarkan Wilayah }\end{array}$ & Berhasil & Berhasil \\
\hline 7. & $\begin{array}{l}\text { Identifikasi Data yang } \\
\text { berusia anatara } 6-8 \\
\text { tahun }\end{array}$ & Berhasil & Berhasil \\
\hline 8. & $\begin{array}{l}\text { Menampilkan } \text { Grafik } \\
\text { Hasil Identifikasi }\end{array}$ & Berhasil & Berhasil \\
\hline & $\begin{array}{l}\text { Berdasarkan } \\
\text { Kelompok Usia } 6-8 \\
\text { tahun }\end{array}$ & & \\
\hline 9. & $\begin{array}{l}\text { Identifikasi Data yang } \\
\text { berusia antara 9-11 } \\
\text { tahun }\end{array}$ & Berhasil & Berhasil \\
\hline 10 & $\begin{array}{l}\text { Menampilkan Grafik } \\
\text { Hasil Identifikasi } \\
\text { Berdasarkan } \\
\text { Kelompok Usia } \\
\text { tahun }\end{array}$ & Gagal & Berhasil \\
\hline 11 & $\begin{array}{ll}\text { Identifikasi } & \text { Data } \\
\text { berdasarkan } & \text { jenis } \\
\text { kelamin } & \end{array}$ & Berhasil & Berhasil \\
\hline 12 & $\begin{array}{lr}\text { Menampilkan } & \text { Grafik } \\
\text { Hasil Identifikasi } \\
\text { Berdasarkan } & \text { Jenis } \\
\text { Kelamin } & \end{array}$ & Berhasil & Berhasil \\
\hline 13 & $\begin{array}{ll}\text { Menampilkan Grafik } \\
\text { Hasil Keseluruhan } \\
\text { Prediksi }\end{array}$ & Berhasil & Berhasil \\
\hline 14 & $\begin{array}{l}\text { Menampilkan } \\
\text { Deskripsi Pada Peta }\end{array}$ & Berhasil & Berhasil \\
\hline
\end{tabular}

Pengujian juga dilakukan untuk mengukur kelayakan identifikasi kecanduan game oleh sistem dengan pakar psikolog perkembangan anak. Uji coba ini menggunakan 20 sampel dummy. Uji coba manual menggunakan kuisioner manual yang diisi. Sementara data yang sama juga diisi pada sistem. Nilai Keeratan kesepakatan antara hasil pengujian secara manual dan aplikasi yang dikembangkan didapat melalui persamaan 1 ,

$K=\frac{\operatorname{Pr}(a)-\operatorname{Pr}(e)}{1-\operatorname{Pr}(e)}$

di mana :

$\operatorname{Pr}(\mathrm{a})=$ Persentase jumlah pengukuran yang konsisten antar rater.
$\operatorname{Pr}(\mathrm{e})=$ Persentase jumlah perubahan pengukuran antar rater.

Tabel 2. Matriks Perbandian Pengujian

\begin{tabular}{lccc}
\hline Uji Manual & \multicolumn{3}{c}{ Identifikasi IGIS Decandu } \\
& Kecanduan & $\begin{array}{c}\text { Tidak } \\
\text { Kecanduan }\end{array}$ & Total \\
\hline $\begin{array}{l}\text { Kecanduan } \\
\text { Tidak }\end{array}$ & 14 & 0 & 14 \\
$\begin{array}{l}\text { Kecanduan } \\
\text { Total }\end{array}$ & 0 & 6 & 6 \\
\hline
\end{tabular}

Di mana :

$\operatorname{Pr}(\mathrm{a})=\frac{14+6}{20}=1.0$

Hasil pengukuran kecanduan game menggunakan

Sistem : $\frac{14+0}{20}=\frac{14}{20}=0.7$

Manual : $\frac{14+0}{20}=\frac{14}{20}=0.7$

Hasil pengukuran tidak kecanduan game menggunakan

Model : $\frac{6+0}{20}=\frac{6}{20}=0.3$

Manual : $\frac{0+6}{20}=\frac{6}{20}=0.3$

Perubahan kemungkinan hasil perhitungan :

Kecanduan $\quad: 0,7 \times 0,7=0,49$

Tidak Kecanduan : 0,3 X 0,3 $=0,09$

Total pengukuran antar rater :

$\operatorname{Pr}(\mathrm{e})=0,42+0,09=0,51$

Nilai Koefisien Cohen's Kappa menggunakan Persamaan 1.

$k=\frac{1.0-0,51}{1-0,51}=1.0$

Ditunjukkan pada Tabel 3 interpretasi Cohen's Kappa sebagai berikut:

Tabel 3. Keeratan Kesepakatan

\begin{tabular}{cc}
\hline Nilai Kappa & Keeratan Kesepakatan \\
\hline $0.00-0.20$ & Sangat Rendah \\
$0.21-0.40$ & Rendah \\
$0.41-0.60$ & Cukup \\
$0.61-0.80$ & Kuat \\
$0.81-1.00$ & Sangat Kuat \\
\hline
\end{tabular}

Pengujian hasil perhitungan diperoleh nilai Kappa sebesar 1.0 antara pengujian sistem IGISDecandu dan ujicoba manual. Berdasarkan hal tersebut, dapat disimpulkan bahwa Sistem IGISDecandu siap untuk digunakan secara umum, karena proses identifikasi kecanduan game valid dengan 
keeratan kesepakatan antara pengujian sistem dan manual adalah 1.00 yang berarti "Sangat Kuat".

\section{KESIMPULAN DAN SARAN}

Telah dihasilkan sebuah aplikasi berbasis web yang dapat digunakan untuk identifikasi kecanduan game dan memetakan hasil identifikasi kedalam peta wilayah Indonesia Dengan adanya aplikasi ini, dapat diketahui persebaran tingkat kecanduan game anakanak Indonesia. Diharapkan aplikasi ini dapat digunakan sebagaimana mestinya dan dapat dijadikan pedoman bagi orang tua dalam mengawasi anaknya dalam bermain game. Karena bagaimanapun, orang tua memiliki peran penting dalam perkembangan anak.

Saran untuk penelitian selanjutnya, sistem dapat dikembangkan dengan menambahkan informasi tentang dampak dari kecanduan game serta cara penanganannya untuk berbagai tingkatan usia baik usia dini, remaja dan dewasa.

\section{UCAPAN TERIMA KASIH}

Terima kasih kepada DIREKTORAT RISET DAN PENGABDIAN MASYARAKAT (DRPM) yang telah memberikan hibah penelitian, sehingga adanya sistem IGIS-Decandu. Terima kasih juga kepada PPA Anugerah Kudus atas kesediannya sebagai mitra dalam memberikan data yang dibutuhkan dalam penelitian ini.

\section{DAFTAR PUSTAKA}

ANONIM, 2019. Gaming Disorder, ICD-11 for Mortality and Morbidity Statictics Version: 04/2019, [online] Tersedia melalui: $<$ https://icd.who.int/browse11/1m/en\#/http://id.who.int/icd/entity/14485972 34> [Diakses 27 Agustus 2019]

ARIANTORO, T.R., 2016. Dampak Game Online Terhadap Prestasi Belajar Pelajar. JUTIM, Vol. 1 No.1. 45-50. Lubuklinggau: STMIK MUSIWARAS.

AYU, L. dan SARAGIH, S., 2016. Interaksi Sosial dan Konsep Diri dengan Kecanduan Game Online pada Dewasa Awal. Jurnal Psikologi Indonesia Persona, Vol.5 No.2. 167-173.

FIATI, R. dan LATUBESSY, A., 2016. Mapping of Flooded Areas in the Kudus District. Indonesian Journal of Electrical Engineering and Computer Science, 2016, 4(3). doi: http://dx.doi.org/10.11591/ijeecs.v4.i3.pp. 670-677.

LATUBESSY, A. dan AHSIN, M.N., 2016. Hubungan Antara Adiksi Game Terhadap Keaktifan Pembelajaran Anak Usia 9-11 Tahun. Simetris, vol 7 No 2, 687-692. Kudus:Penerbit UMK.
LATUBESSY, A. dan JAZULI, A., 2017. Analisis Model Penelusuran Backward Chaining dalam Mendeteksi Tingkat Kecanduan Game pada Anak, JTSISKOM, Vol 5 No 4, 129-134. Semarang: Department of Computer Engineering, Faculty of Engineering, Universitas Diponegoro

LATUBESSY, A. dan JAZULI, A., 2018. Web Application to Measure Level of Addictive Game. International Journal of Engineering and Technology. Vol.7 No.3.1791-1794. UAE: Science Publishing Corporation.

LATUBESSY, A. dan WIJAYANTI, E., 2017. Model Identifikasi Kecanduan Game Menggunakan Backward Chaining. Simetris, Vol 8 No 1, 9-14. Kudus:Penerbit UMK.

MISNAWATI, 2016. Hubungan antara Kecerdasan Emosi dengan Kecanduan game Online pada Siswa-Siswi di SMP YPS(Yayasan Pendidikan Samarinda. Psikoborneo, Vol.4 No.2. 312-329.

SETIAJI, S. dan VIRLIA, S., 2016. Hubungan Kecanduan Game Online dan Ketrampilan Sosial pada Pemain Game Dewasa Awal di Jakarta Barat. Jurnal Psikologi Psibernetika, Vol. 9 No,2. 92-101.

SYAHRAN, R. 2015. Ketergantungan Online Game dan Penanganannya, Jurnal Psikologi Pendidikan \& Konseling. Vol.1 No.1. 84-92.

ULFA, M. 2017. Pengaruh Kecanduan Game Online Terhadap Perilaku Remaja di Mabes Game Center Jalan Hr.Subrantas Kecamatan Tampan Pekanbaru. JOM.FISIP Vol.4 No.1. $1-13$. 